\title{
Article
}

\section{Amorphous $\mathrm{CoO}_{x}$ coupled carbon dots as a spongy porous bifunctional catalyst for efficient photocatalytic water oxidation and $\mathrm{CO}_{2}$ reduction}

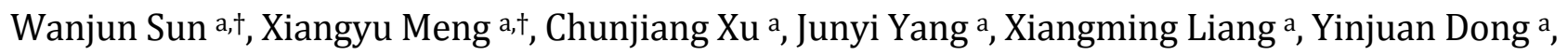 \\ Congzhao Dong a, Yong Ding a,b,* \\ a State Key Laboratory of Applied Organic Chemistry, Key Laboratory of Nonferrous Metals Chemistry and Resources Utilization of Gansu Province, and \\ College of Chemistry and Chemical Engineering, Lanzhou University, Lanzhou 730000, Gansu, China \\ ' State Key Laboratory for Oxo Synthesis and Selective Oxidation, Lanzhou Institute of Chemical Physics, Chinese Academy of Sciences, Lanzhou 730000, \\ Gansu, China
}

\section{A R T I C L E I N F O}

\section{Article history:}

Received 25 February 2020

Accepted 23 March 2020

Published 5 December 2020

\section{Keywords:}

Carbon dots coupled $\mathrm{CoO}_{x}$

Bifunctional photocatalyst

Water oxidation

$\mathrm{CO}_{2}$ reduction

Synergistic effect

\begin{abstract}
A B S T R A C T
Cobalt-based oxides, with high abundance, good stability and excellent catalytic performance, are regarded as promising photocatalysts for artificial photosynthetic systems to alleviate foreseeable energy shortages and global warming. Herein, for the first time, a series of novel spongy porous CDs@ $@ \mathrm{CoO}_{x}$ materials were synthesized to act as an efficient and stable bifunctional photocatalyst for water oxidation and $\mathrm{CO}_{2}$ reduction. Notably, the preparation temperatures visibly influence the

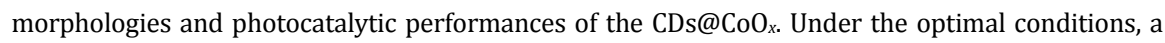
maximum $\mathrm{O}_{2}$ yield of $40.4 \%$ and pretty apparent quantum efficiency (AQE) of $58.6 \%$ at $460 \mathrm{~nm}$

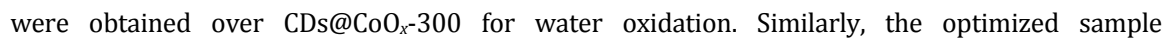
CDs@CoO -300 manifests significant enhancement on the $\mathrm{CO}_{2}$-to-CO conversion with a high selectivity of $89.3 \%$ and $\mathrm{CO}$ generation rate of $8.1 \mu \mathrm{mol} / \mathrm{h}$, which is superior to most previous co-

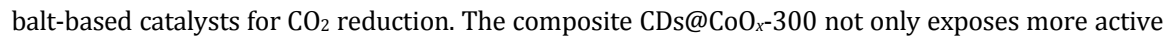
sites but also facilitates electron transport, which results in excellent photocatalytic activity. In addition, the boosted photocatalytic behavior is attributed to the synergistic effect between $\mathrm{CoO}_{x}$ and CDs, which was verified by the photocatalytic activity control experiments and electrochemical characterization. The work offers a novel strategy to fabricate a high performance bifunctional photocatalyst for water oxidation and $\mathrm{CO}_{2}$ reduction.
\end{abstract}

(c) 2020, Dalian Institute of Chemical Physics, Chinese Academy of Sciences. Published by Elsevier B.V. All rights reserved.

\section{Introduction}

Solar-driven photocatalytic water splitting and $\mathrm{CO}_{2}$ reduction are deemed as the best green and promising strategy to alleviate energy shortages and global warming (Eq. (1)) [1-8].
The overall water splitting process comprises two half reactions, namely proton reduction and water oxidation reaction (Eqs. 2 and 3) [9-13]. Compared with proton reduction reaction, water oxidation involves a complicated four-electron transfer process, which is considered as the bottleneck of water

\footnotetext{
* Corresponding author. E-mail: dingyong1@lzu.edu.cn

+ These authors contributed equally to this work.

This work was supported by the National Natural Science Foundation of China (21773096), Fundamental Research Funds for the Central Universities (lzujbky-2018-k08) and the Natural Science Foundation of Gansu (17JR5RA186).

DOI: 10.1016/S1872-2067(20)63646-4 | http://www.sciencedirect.com/science/journal/18722067 | Chin. J. Catal., Vol. 41, No. 12, December 2020
} 
splitting $[14,15] . \mathrm{CO}_{2}$ reduction is an important half-reaction of photosynthesis (Eq. (4)), which is a typical thermodynamically uphill reaction with large overpotential [16-19]. Hence, the search for suitable catalysts to reduce the multielectron involved kinetic barriers for water oxidation and $\mathrm{CO}_{2}$ reduction is considered as a critical step toward artificial photosynthesis [20-22]. It is highly desirable to seek robust, efficient and earth abundant catalysts with bifunctional performance for simultaneous photocatalytic water oxidation and $\mathrm{CO}_{2}$ reduction in artificial photosynthetic systems [23,24].

$$
\begin{gathered}
6 \mathrm{CO}_{2}+12 \mathrm{H}_{2} \mathrm{O} \rightarrow \mathrm{C}_{6} \mathrm{H}_{12} \mathrm{O}_{6}+6 \mathrm{O}_{2}+6 \mathrm{H}_{2} \mathrm{O} \\
2 \mathrm{H}^{+}+2 \mathrm{e}^{-} \rightarrow \mathrm{H}_{2} \\
2 \mathrm{H}_{2} \mathrm{O}-4 \mathrm{e}^{-} \rightarrow \mathrm{O}_{2}+4 \mathrm{H}^{+} \\
\mathrm{CO}_{2}+n \mathrm{e}^{-}+m \mathrm{H}^{+} \rightarrow \mathrm{CO}, \mathrm{CH}_{4} \text { etc. }
\end{gathered}
$$

Cobalt-based homogeneous and heterogeneous catalysts have been proved as attractive candidates for this purpose [25-29]. Particularly, cobalt-based heterogeneous catalysts, such as cobalt oxide, are usually robust, cheap, and easy to prepare [30-34]. However, their photocatalytic performance still need to be further improved for practical large-scale applications. Previous studies showed that amorphous phase catalysts as photocatalytically were inactive, which they focused on crystalline rather than amorphous phase [35,36]. But recent works have indicated that the amorphous morphology of cobalt-based oxides play a critical role in enhancing their photocatalytic performance [37-41]. As a new type of carbon nanomaterial containing abundant functional groups, carbon dots (CDs) were discovered in 2004 [42] and exploited for photocatalytic properties in 2010 [43]. Owing to its unique optical and electronic properties, CDs can serve as a versatile component in reported photocatalysts [44-48]. However, the CDs coupled $\mathrm{CoO}_{x}$ has never been studied as a bifunctional photocatalyst in dye-sensitizing water oxidation and $\mathrm{CO}_{2}$ reduction systems.

Herein, a series of spongy porous bifunctional photocatalysts CDs@ $\mathrm{CoO}_{x}$ were synthesized by controlling the crystallinity of the catalysts with changing the calcination temperature, which enhances the $\mathrm{CoO}_{x}$ photocatalytic activity assisted by CDs. Under the optimal conditions, a maximum $\mathrm{O}_{2}$ yield of $40.4 \%$ and an apparent quantum efficiency (AQE) of 58.6\%

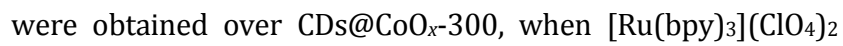
was used as photosensitizer and $\mathrm{Na}_{2} \mathrm{~S}_{2} \mathrm{O}_{8}$ as sacrificial electron acceptor in borate buffer solution ( $\mathrm{pH}$ 9.0). For the $\mathrm{CO}_{2}$ reduction, a CO selectivity of $89.3 \%$ and a CO generation rate of 8.1 $\mu \mathrm{mol} / \mathrm{h}$ were got when $\left[\mathrm{Ru}(\mathrm{bpy})_{3}\right] \mathrm{Cl}_{2}$ was used as photosensitizer and triethanolamine (TEOA) as electron donor. This work provides a promising route for developing stable cobalt-based carbon hybrids photocatalysts with high-performance for artificial photosynthesis.

\section{Experimental}

\subsection{Synthesis of CDs@CoO}

Firstly, the carbon dots (CDs) were synthesized by a "bottom-up" approach according to a previous literature with some modifications [49]. In a typical synthesis procedure, the mix- tures of dicyandiamide $(1.0 \mathrm{~g})$ and glucose $(0.2 \mathrm{~g})$ (the mass ratio of two components is 5: 1) were dissolved in $10 \mathrm{~mL}$ deionized water, and transferred to a $25 \mathrm{~mL}$ Teflon autoclave, heating at $200{ }^{\circ} \mathrm{C}$ for $6 \mathrm{~h}$. After the reaction, the mixture was cooled to room temperature naturally. The resulting product was filtered by a $0.22 \mu \mathrm{m}$ filter to remove the large particles and get the uniform red-brown CDs solution. After removing solvent and freeze-drying further, the CDs powder was obtained and stored at $4{ }^{\circ} \mathrm{C}$, which can be redispersed in ultrapure water for further characterization.

Subsequently, the $0.2 \mathrm{~g} \mathrm{Co}\left(\mathrm{NO}_{3}\right)_{2} \cdot 6 \mathrm{H}_{2} \mathrm{O}$ was added in the above CDs solution under stirring for $30 \mathrm{~min}$, then dried at 60 ${ }^{\circ} \mathrm{C}$ to collect the $\mathrm{CDs}-\mathrm{Co}^{2+}$ powder. Finally, the black powder was annealed at $300{ }^{\circ} \mathrm{C}$ in a muffle furnace for $2 \mathrm{~h}$ (rate: 5

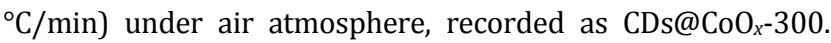

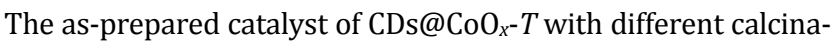
tion temperatures $\left(T=200,300,400\right.$ and $\left.600{ }^{\circ} \mathrm{C}\right)$ were denoted as CDs@CoO $x-200,300,400$ and 600, respectively. For comparison, the bare $\mathrm{Co}_{3} \mathrm{O}_{4}$ catalyst was prepared by the same way without adding the above acquired CDs.

\subsection{Photocatalytic oxygen evolution and $\mathrm{CO}_{2}$ reduction}

The photocatalytic water oxidation experiments were investigated in a $25 \mathrm{~mL}$ flask ( $10 \mathrm{~mL}$ reaction solution) at room temperature and irradiated by a LED (Beijing Perfectlight, PLS-LED100, $\lambda=460 \mathrm{~nm}$, light intensity $=33.8 \mathrm{~mW} / \mathrm{cm}^{2}$ ). The desired concentration of catalyst was dispersed in borate buffer solution $(80 \mathrm{mM})$ with different $\mathrm{pH}$ containing $5 \mathrm{mM}$ $\mathrm{Na}_{2} \mathrm{~S}_{2} \mathrm{O}_{8}$ as electron acceptor and $1 \mathrm{mM}\left[\mathrm{Ru}(\mathrm{bpy})_{3}\right] \mathrm{Cl}_{2} \cdot 6 \mathrm{H}_{2} \mathrm{O}$ (bpy $=2,2^{\prime}$-bipyridine) as photosensitizer. Before photoreaction, the air inside photoreactor was deaerated by evacuation and purged with Ar gas several times and maintained the similar pressure in the reactor as atmospheric pressure. The amount of generated gas at the headspace of the reaction flask was withdrawn by an SGE gastight syringe and analyzed by gas chromatography (5 A column with Ar carrier gas, Shimadzu GC-9A Gas) equipped with thermal conductivity detector (TCD).

The $\mathrm{CO}_{2}$ reduction performance was tested by combining the catalysts $(0.5 \mathrm{mg})$ and the $7.5 \mathrm{mg}\left[\mathrm{Ru}(\mathrm{bpy})_{3}\right] \mathrm{Cl}_{2} \cdot 6 \mathrm{H}_{2} \mathrm{O}$ in a gas-closed quartz reactor which contains $\mathrm{MeCN} / \mathrm{H}_{2} \mathrm{O} / \mathrm{TEOA}(3$ $\mathrm{mL} / 2 \mathrm{~mL} / 1 \mathrm{~mL}$ ) mixture solution. Before illumination, the $\mathrm{CO}_{2}$ gas was filled into the reactor for about $10 \mathrm{~min}$ to replacement

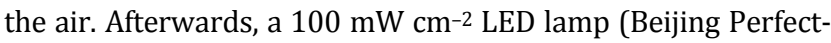
light, PLS-LED100B, $\lambda=460 \mathrm{~nm}$ ) was used as the light source. After a period of irradiation, a gas chromatography was used to detect the products (Shimadzu GC-9AMM Gas, CO was analyzed by thermal conductivity detectors).

\section{Results and discussion}

\subsection{Characterization of CDs and CDs@CoO}

The preparation diagram of the $\mathrm{CDs@CoO}$ photocatalyst is schematically depicted in Scheme 1. The CDs were synthesized by dehydration and polymerization via a facile one-pot hydro- 


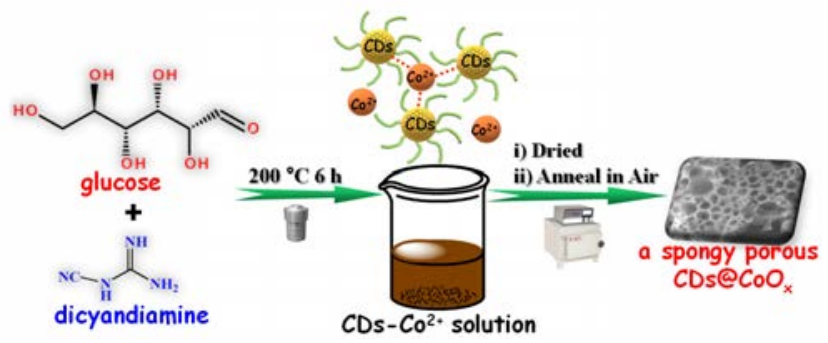

Scheme 1. Illustration of the preparation of $\mathrm{CDs} @ \mathrm{CoO}_{x}$.

thermal route at $200{ }^{\circ} \mathrm{C}$ for $6 \mathrm{~h}$. After adding $0.2 \mathrm{~g}$ of $\mathrm{Co}\left(\mathrm{NO}_{3}\right)_{2} \cdot 6 \mathrm{H}_{2} \mathrm{O}$ to the obtained $\mathrm{CDs}-\mathrm{Co}^{2+}$ solution, the mixtures were dried at $60{ }^{\circ} \mathrm{C}$ and then treated with different calcination temperatures under air atmosphere to form $\mathrm{CDs@CoO}$ photocatalysts.

The successful preparation of the CDs was proved by the TEM and HR-TEM images. Fig. 1 shows the spherical and uniformly distributed carbon particles (2-6 $\mathrm{nm}$ in diameter) with a lattice spacing of $0.19 \mathrm{~nm}$, corresponding to the [102] lattice plane spacing of graphitic carbon in the inserted (Fig. 1(b)) [50].

The functional groups of obtained CDs were measured by FT-IR spectra in Fig. S1, where the characteristic peaks at 3446, 1635,1400 and $1255 \mathrm{~cm}^{-1}$ can be assigned to the stretching vibration of $\mathrm{O}-\mathrm{H}, \mathrm{C}=\mathrm{C} / \mathrm{C}=\mathrm{O}[51], \mathrm{C}-\mathrm{N}$ and $\mathrm{C}-\mathrm{C}[52,53]$, respec-

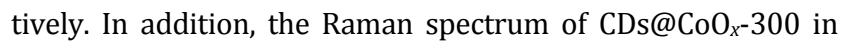
Fig. S2 reveals the presence of the fabrication of graphitic carbon (typical D and G bands at $1200-1600 \mathrm{~cm}^{-1}$ ).

As shown in Fig. 2, the bare $\mathrm{Co}_{3} \mathrm{O}_{4}$ is confirmed by XRD and matched well with its standard XRD pattern (JCPDS PDF No. 73-1701) [54]. When CDs are incorporated into $\mathrm{CoO}_{x}$, the CDs@CoO ${ }_{x}$ samples at 200 and $300{ }^{\circ} \mathrm{C}$ show very poor crystallinity, indicating that they are nearly amorphous composite. Upon calcination at a higher temperature of 400 or $600{ }^{\circ} \mathrm{C}$, the

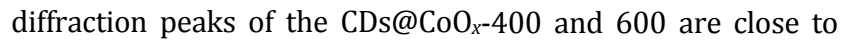
that of the bare $\mathrm{Co}_{3} \mathrm{O}_{4}$, indicating the better crystallinity of the sample prepared at a higher temperature.

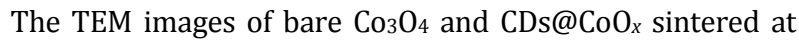
different calcination temperature $\left(200,300,400\right.$ and $\left.600{ }^{\circ} \mathrm{C}\right)$ are presented in Figs. S3, S4 and 3. The bare $\mathrm{Co}_{3} \mathrm{O}_{4}$ shows an aggregated rodlike structure which was acquired by one-pot pyrolysis at $300{ }^{\circ} \mathrm{C}$. When incorporated of CDs, the morphology

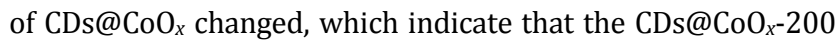
and $\mathrm{CDs} @ \mathrm{CoO}_{x}-300$ are spongy porous morphology structures with pore sizes ranging from several tens to hundreds of na-
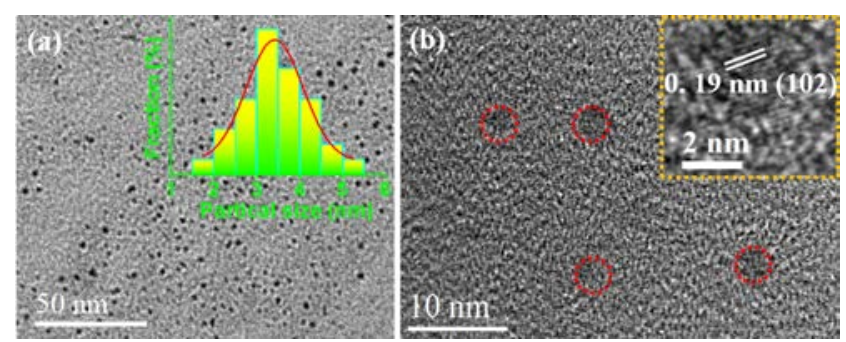

Fig. 1. TEM (inset: size distribution) (a) and HR-TEM (b) images (inset: lattice fringe image) of CDs.

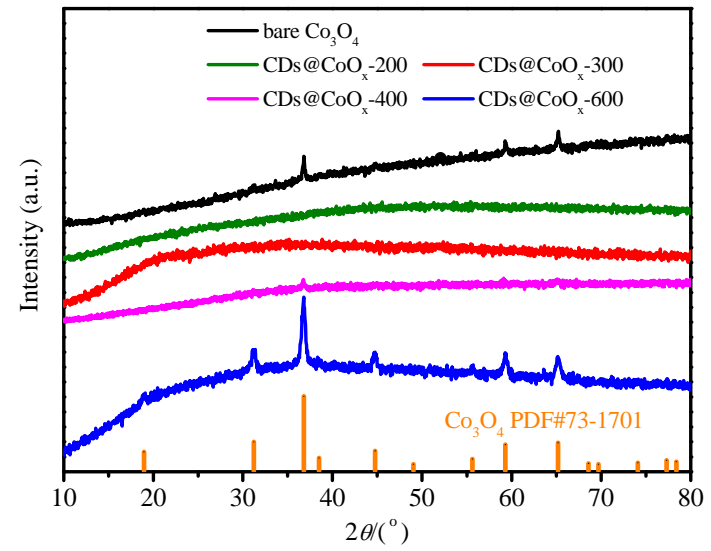

Fig. 2. XRD patterns of bare $\mathrm{Co}_{3} \mathrm{O}_{4}$ and $\mathrm{CDs} @ \mathrm{CoO}_{x}$ catalysts.

nometers based on SEM and TEM results (Fig. 3(a) and 3(b)), respectively. The formation of porous property may be attributed to the release of gas molecules during the decomposition and recrystallization process [55]. As the calcination tem-

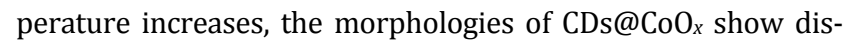
persive particles in Figs. S4(c) and S3(e), which the lattice fringe of 0.28 and $0.20 \mathrm{~nm}$ are clearly ascribed the [220] and [400] plane of $\mathrm{Co}_{3} \mathrm{O}_{4}$. These images reveal that the calcination

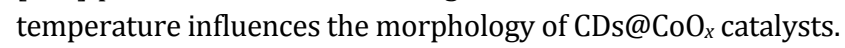

As shown in Fig. 3(e), the lattice fringes of $0.19 \mathrm{~nm}$ is ascribed to the [102] plane of graphitic carbon (dark-colored contrast). However, it is difficult to distinguish the lattice fringes $(0.195 \mathrm{~nm})$ of Co species (light-colored contrast), suggesting

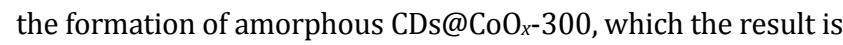
agreement with the results of XRD analysis. Moreover, the selected area electron diffraction (SAED) measurement of CDs@ $\mathrm{CoO}_{x}-300$ in the inserted Fig. 3(e) shows no diffraction spots or rings, indicating its amorphous feature. The elemental mapping images (Fig. 3(f)-(i)) show that the Co, C, N and $\mathrm{O}$ elements are distributed uniformly in the selected detection area of the hybrid material. The Inductively Coupled Plasma Atomic Emission Spectroscopy (ICP-AES) indicates that the cobalt content in CDs@CoO ${ }_{x}-300$ is $242.5 \mathrm{mg} / \mathrm{g}$.

More importantly, the surface chemical compositions and

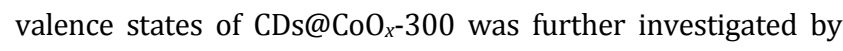

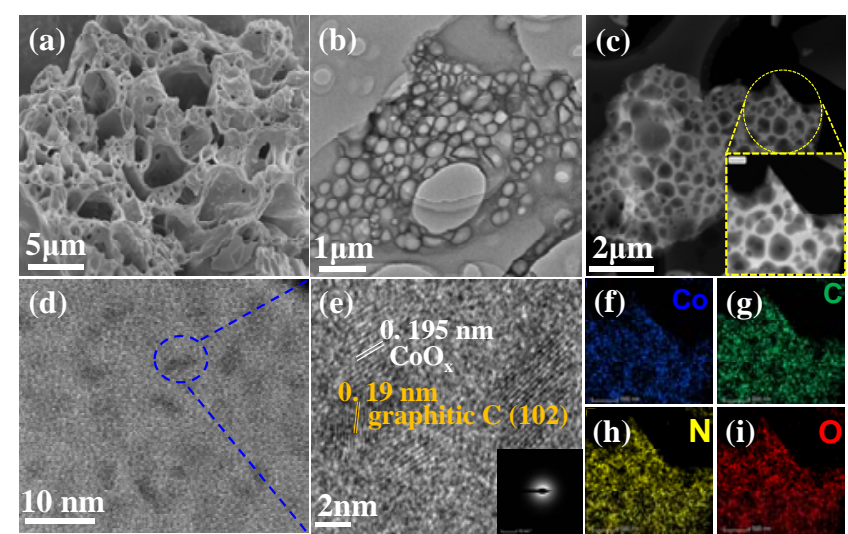

Fig. 3. SEM (a) and TEM (b, c) and HR-TEM (d, e) images and element mapping image (f-i) of $\mathrm{CDs} @ \mathrm{CoO}_{x}-300$. 


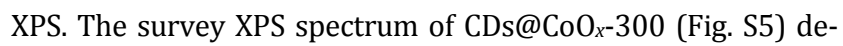
picts that the composite contains the elements $\mathrm{C}, \mathrm{O}$, Co and $\mathrm{N}$. The five peaks at 284.2/284.8, 285.3, 286.1, and $288.3 \mathrm{eV}$ in Fig. 4(a) are ascribed to $\mathrm{C}=\mathrm{C} / \mathrm{C}-\mathrm{C}, \mathrm{C}-\mathrm{N}, \mathrm{C}-\mathrm{OH}$, and $\mathrm{COOH}$, respectively. The $\mathrm{N} 1 s$ spectrum (Fig. 4(b)) fitted into three peaks at $399.1,400.1$ and $400.8 \mathrm{eV}$, which are corresponding to graphitized $\mathrm{N}$, pyrrolic $\mathrm{N}$ and pyridinic $\mathrm{N}$, respectively. The $\mathrm{O} 1 \mathrm{~s}$ peaks at 532.0 and $533.2 \mathrm{eV}$ display $\mathrm{C}=\mathrm{O} / \mathrm{O}-\mathrm{C}-\mathrm{OH}$ and $\mathrm{C}-\mathrm{OH}$ (Fig. 4(c)), respectively. In addition, the $01 s$ peak XPS peak at $531.85 \mathrm{eV}$ can be assigned to the lattice oxygen in the $\mathrm{Co}_{3} \mathrm{O}_{4}$ phase [56], which demonstrates the presence of $\mathrm{Co}_{3} \mathrm{O}_{4}$ in the CDs@CoO ${ }_{x}$. In the high-resolution Co $2 p$ spectrum (Fig. 4(d)), the four peaks for $2 p_{1 / 2} / 2 p_{3 / 2}$ of $\mathrm{Co}^{2+}$ and $\mathrm{Co}^{3+}$ locate at 781.1/797.1 and 783.2/798.5 eV, where the corresponding satellite peaks are at 786.5 and $802.7 \mathrm{eV}$. Furthermore, the Co $2 p_{3 / 2}-2 p_{1 / 2}$ spin-orbit splitting $(\Delta E)$ is $15.3 \mathrm{eV}$ for $\mathrm{Co}_{3} \mathrm{O}_{4}$ and $16.0 \mathrm{eV}$ for $\mathrm{CoO}$ [57], respectively. Therefore, we conclude that the species of Co can be attributed to a mixture of $\mathrm{Co}^{2+}$ and $\mathrm{Co}^{3+}$, which is denoted as $\mathrm{CoO}_{x}$ for simplicity in the hybrid material.

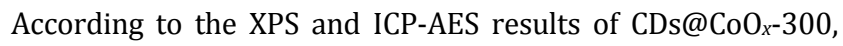

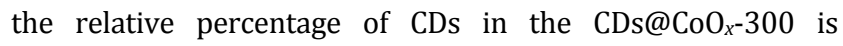
$66.97 \%-69.16 \%$.

\subsection{Photocatalytic water oxidation}

The CDs@CoO ${ }_{x}$ for water oxidation were performed using the classical established $\left[\mathrm{Ru}(\mathrm{bpy})_{3}\right] \mathrm{Cl}_{2} /$ catalyst/visible light/ $\mathrm{Na}_{2} \mathrm{~S}_{2} \mathrm{O}_{8}$ system [58]. The kinetic curves of $\mathrm{O}_{2}$ evolution with different catalysts are depicted in Fig. 5. Obviously, no or only a trace amount of $\mathrm{O}_{2}$ was detected in the absence of any
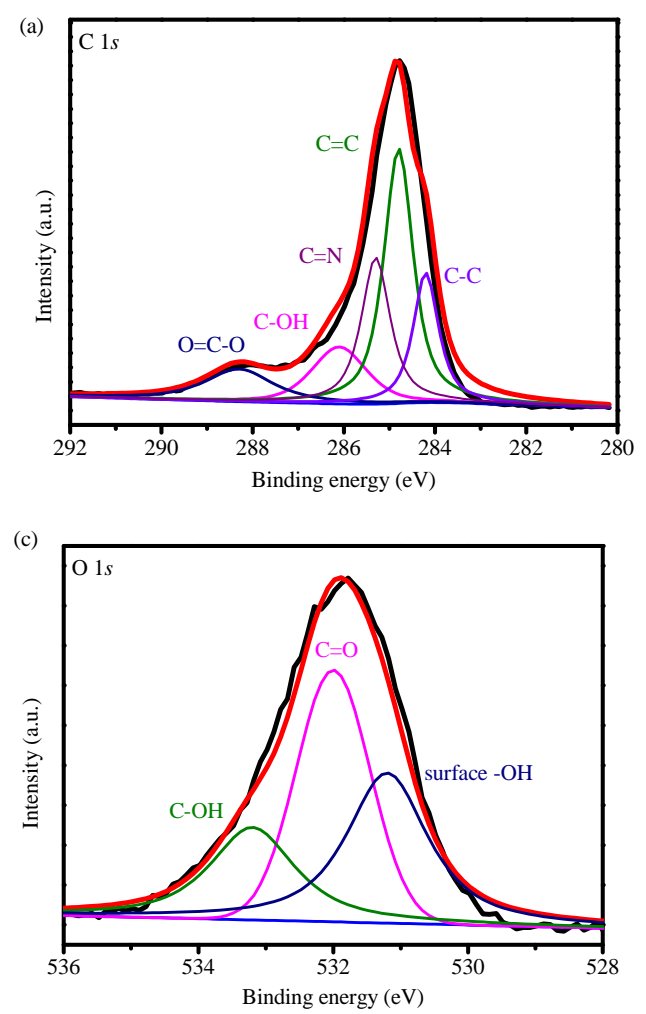

ingredients, which reveals that light irradiation, photosensitizer $\left(\left[\mathrm{Ru}(\mathrm{bpy})_{3}\right] \mathrm{Cl}_{2}\right)$ and electron sacrificial acceptor $\left(\mathrm{Na}_{2} \mathrm{~S}_{2} \mathrm{O}_{8}\right)$ as well as the catalyst are indispensable for efficient visible-light-driven water oxidation reaction.

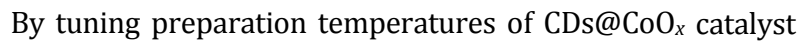
$\left(200,300,400\right.$ or $\left.600{ }^{\circ} \mathrm{C}\right)$, it can be noted that the ${\mathrm{CDs} @ \mathrm{CoO}_{x}}$ with poor crystallinity material shows better photocatalytic

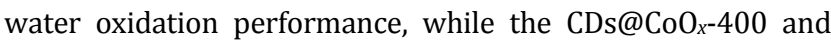
CDs@CoO -600 samples with high crystallinity exhibit the relatively poor water oxidaiton activity. Such phenomenon indicates that the incorporation of CDs is beneficial to form amorphous CDs@CoO ${ }_{x}-300$, which is more favorable for water oxidation. This finding is in accordance with supplements previous reported results and establishes that amorphous cobalt-based carbon hybrids can be suitable as WOCs for light-driven water oxidation.

When a small amount of CDs@CoO $x^{-} 300(0.01 \mathrm{~g} / \mathrm{L})$ was added, $4.6 \mu \mathrm{mol} \mathrm{O}_{2}$ was released dramatically within initial light irradiation $30 \mathrm{~s}$, indicating that $\mathrm{CDs@CoO}$-300 truly serves as a catalyst for boosting the oxidation of water. Then the control experiments were optimized through varying different the $\mathrm{pH}$ value of the borate buffer solution $(\mathrm{pH}=8.5,9.0$ or 9.5) and mass concentration of catalysts $(0.01,0.1,0.2$ or 0.5 g/L) (Figs. S8-S10). The highest oxygen evolution amount was obtained using $0.2 \mathrm{~g} / \mathrm{L}$ of $\mathrm{CDs} @ \mathrm{CoO}_{x}-300$ in the pH 9.0 of borate buffer solution $(80 \mathrm{mM}, 10 \mathrm{~mL})$. In the initial reaction, the conditions were optimal. In general, a higher $\mathrm{pH}$ value was thermodynamically favorable for water oxidation and a fast rate in the initial reaction would be obtained. But as time goes on, on the one hand, the solution of $\mathrm{pH}$ value decreased gradu-
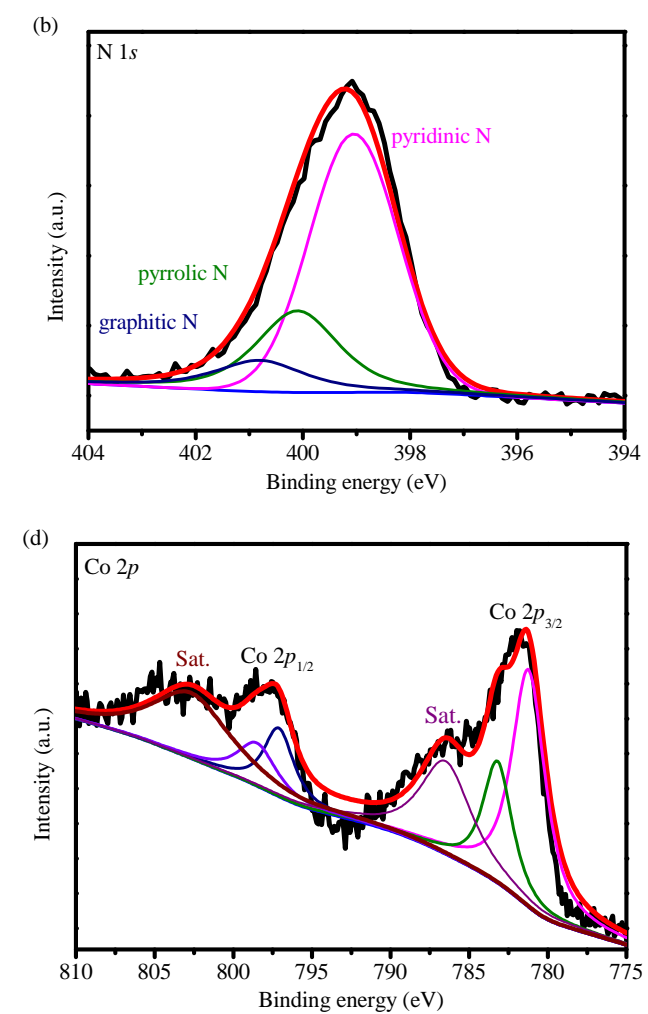

Fig. 4. High-resolution XPS spectra of C $1 s$ (a), N $1 s$ (b), $01 s$ (c) and Co $2 p$ (d) for CDs@CoO -300. 

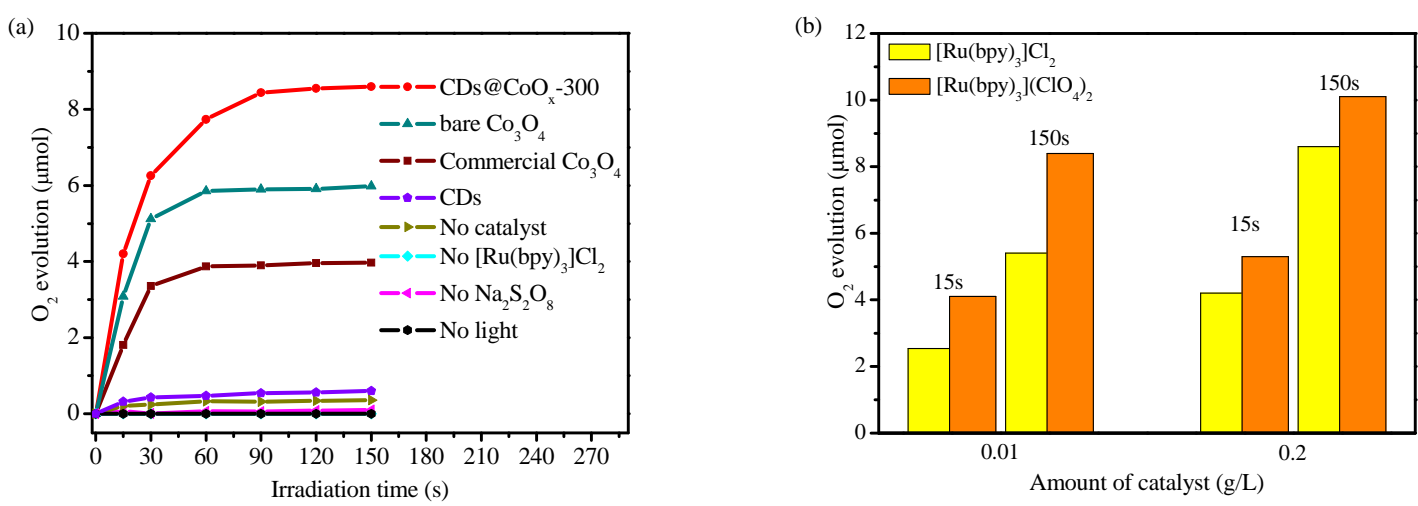

Fig. 5. (a) Kinetics of oxygen evolution in the photocatalytic system using different $0.2 \mathrm{~g} / \mathrm{L}$ catalyst; (b) amount of oxygen evolution using different photosensitizers. Conditions: $5 \mathrm{mM} \mathrm{Na}_{2} \mathrm{~S}_{2} \mathrm{O}_{8}, 1 \mathrm{mM}$ photosensitizers and $10 \mathrm{~mL} 80 \mathrm{mM}$ borate buffer solution ( $\mathrm{pH} 9.0$ ) at $\lambda_{\mathrm{LED}}=460 \mathrm{~nm}$ irradiation.

ally, which was thermodynamically unfavorable for water oxidation. On the other hand, the sacrificial electron acceptor of $\mathrm{Na}_{2} \mathrm{~S}_{2} \mathrm{O}_{8}$ was consumed up and photosensitizer of $\left[\mathrm{Ru}(\mathrm{bpy})_{3}\right] \mathrm{Cl}_{2}$ was decomposed during the photocatalytic process. Therefore, $\mathrm{O}_{2}$ evolution rate began to decrease over time and reached a platform in $120 \mathrm{~s}$.

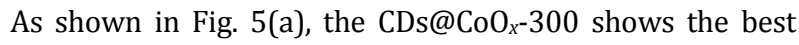
catalytic activity among all photocatalysts evaluated under light driven water oxidation system. A maximum $\mathrm{O}_{2}$ yield of $34.4 \%$ (8.6 $\mu \mathrm{mol}$ ) is obtained in the presence of CDs@CoO $x-300$, which is larger than those of $\mathrm{CDs} @ \mathrm{CoO}_{x}-200$ (26.4\%, 6.6 $\left.\mu \mathrm{mol}\right)$, CDs@CoO $x^{-} 400$ (28.4\%, $\left.7.1 \mu \mathrm{mol}\right)$ and CDs@CoO -600 (19.2\%, $4.8 \mu \mathrm{mol})$. In addition, a low $\mathrm{O}_{2}$ yield of commercial $\mathrm{Co}_{3} \mathrm{O}_{4}$ $(15.9 \%, 4 \mu \mathrm{mol})$ and bare $\mathrm{Co}_{3} \mathrm{O}_{4}(24.0 \%, 6 \mu \mathrm{mol})$ were measured. Moreover, there is no $\mathrm{O}_{2}$ evolution was detected in the presence of CDs.

When $\left[\mathrm{Ru}(\mathrm{bpy})_{3}\right] \mathrm{Cl}_{2}$ was replaced by with the $\left[\mathrm{Ru}(\mathrm{bpy})_{3}\right]\left(\mathrm{ClO}_{4}\right)_{2}$ as photosensitizer, $\mathrm{CDs} @ \mathrm{CoO}_{x}-300$ exhibited better activity for water oxidation with an high $\mathrm{O}_{2}$ yield and AQE. The possible reason for the improved water oxidation activity is as follow: $\mathrm{Cl}^{-}$will consume the sacrificial reagent through transferring electrons to $\mathrm{SO}_{4}{ }^{--}$thereby forming $\mathrm{Cl}_{2}$, thus decreasing the catalytic activity in the photocatalytic water oxidation processes. In contrast, the $\mathrm{Cl}$ in $\mathrm{Ru}(\mathrm{bpy})_{3}\left(\mathrm{ClO}_{4}\right)_{2}$ has reached the highest valence and will not react with $\mathrm{SO}_{4}{ }^{--}$to form other oxidative products [59]. Thus, the enhanced catalytic activity is obtained when $\left[\mathrm{Ru}(\mathrm{bpy})_{3}\right]\left(\mathrm{ClO}_{4}\right)_{2}$ is used as a photosensitizer. As shown in Table $\mathrm{S} 1$, the $\mathrm{O}_{2}$ yield $40.4 \%$ is in moderate level among all reported heterogeneous cobalt-based WOCs. AQE of CDs@CoO -300 is 58.6\%, which is the third highest value among all reported heterogeneous cobalt-based WOCs. The outstanding results show that the synergistic effect between $\mathrm{CoO}_{x}$ and CDs leads to the significantly enhanced photocatalytic water oxidation performance.

In addition, the $\left[\mathrm{Ru}(\mathrm{bpy})_{3}\right] \mathrm{Cl}_{2}$ was selected as a photosensitizer, TEOA was used as sacrificial electron acceptor and CDs@CoO -300 was used as catalyst for photocatalytic hydrogen evolution (Fig. S11). A few amount of $\mathrm{H}_{2}(0.53 \mu \mathrm{mol})$ when $\left[\mathrm{Ru}(\mathrm{bpy})_{3}\right] \mathrm{Cl}_{2}$ was solely added. The amount of hydrogen increased when the catalyst was added. The highest hydrogen evolution amount $(1.43 \mu \mathrm{mol})$ was obtained using $3 \mathrm{mg}$ of
CDs@CoO ${ }_{x}-300$ in $10 \mathrm{~mL}$ 10\% TEOA aqueous solution irradiated for $1 \mathrm{~h}$.

\subsection{Photocatalytic $\mathrm{CO}_{2}$ reduction}

The photocatalytic $\mathrm{CO}_{2}$ reduction performances of all

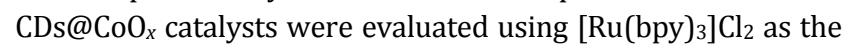
photosensitizer and acetonitrile/ $\mathrm{H}_{2} \mathrm{O} / \mathrm{TEOA}$ mixture as the reaction medium [60]. A series of comparative experiments were conducted to explore the fundamental impact factors determining the activity of the photoreduction catalysts. CO and $\mathrm{H}_{2}$ were detected as the main products without the observation of any other potential products (such as $\mathrm{CH}_{4}$ ), consistent with the reports in previous similar works [61]. Firstly, the influence of the calcinations temperatures on the photocatalyt-

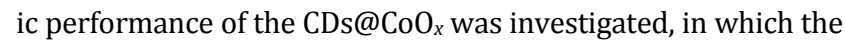
yields of $\mathrm{CO}$ and $\mathrm{H}_{2}$ vary apparently in different samples (Fig. 6(a)). The CDs@CoO $x-300$ with poor crystallinity exhibits the highest $\mathrm{CO}_{2}$ reduction activity among the four samples. The influence of the amount of $\mathrm{CDs} @ \mathrm{CoO}_{x}-300$ for the photocatalytic $\mathrm{CO}_{2}$ reduction was investigated (Fig. 6(b)). When $0.5 \mathrm{mg}$ of CDs@CoO $x-300$ was added, the C0 production rate and selectivity obviously increase. However, the amount of CO evolved decreases with the further increased amount of CDs@CoO $x-300$. The depressed activity may be the following reasons [5]: (1) Excessive catalyst would cover the surface active sites on the photocatalyst and block its contact with reactants of $\mathrm{CO}_{2}, \mathrm{H}_{2} \mathrm{O}$ or TEOA. (2) Too much amount catalyst would prevent the incident light, thus decreasing the number of photogenerated electron-hole pairs.

The control experiments of $\mathrm{CO}_{2}$ reduction were carefully conducted under various reaction conditions as shown in Fig. 6(c). No products were detected in the absence of light, $\left[\mathrm{Ru}(\mathrm{bpy})_{3}\right] \mathrm{Cl}_{2}$, or TEOA, which highlights the indispensability of photosensitizer, sacrificial agent and light illumination for $\mathrm{CO}_{2}$ reduction, respectively (column 1-3). Furthermore, when [Ru(bpy) $\left.{ }_{3}\right] \mathrm{Cl}_{2}$ was solely added, only a little amount of $\mathrm{H}_{2}(0.45$ $\mu \mathrm{mol} / \mathrm{h})$ and CO $(0.37 \mu \mathrm{mol} / \mathrm{h})$ were produced, which fully demonstrates the significance of presence CDs@ $\mathrm{CoO}_{x}-300$ catalyst (column 4). As shown in Fig. 6(c), there is only $0.42 \mu \mathrm{mol}$ amount of $\mathrm{CO}$ produced in the presence of single CDs (column 
(a)

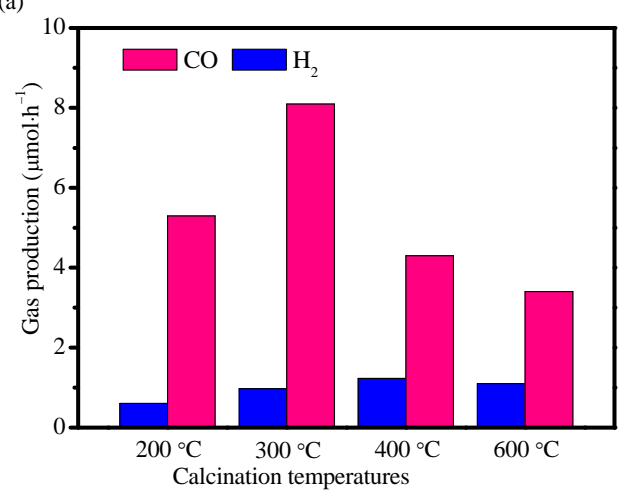

(c)

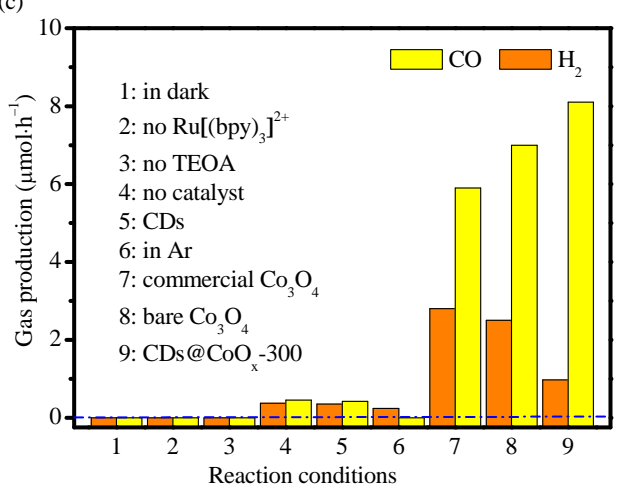

(b)

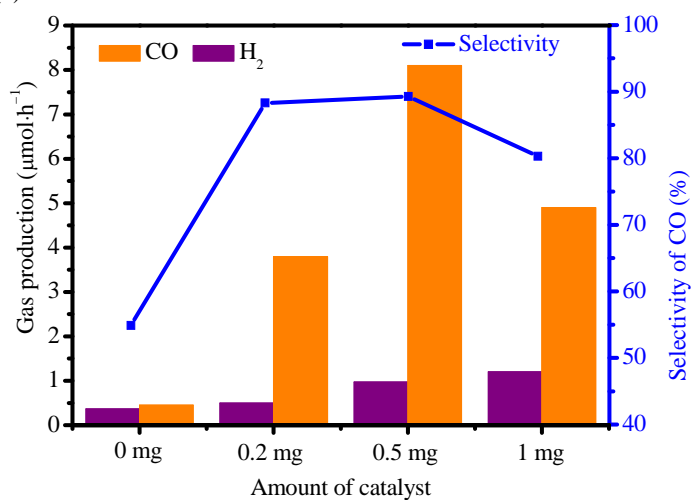

(d)

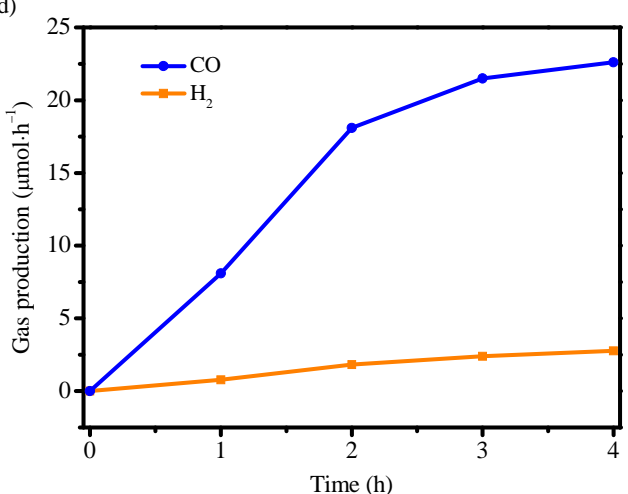

Fig. 6. Generation of $\mathrm{CO}$ and $\mathrm{H}_{2}$ from photoreduction of $\mathrm{CO}_{2}$. (a) Under different calcination temperatures, (b) amount of catalyst of $\mathrm{CDs@CoO}$-300;

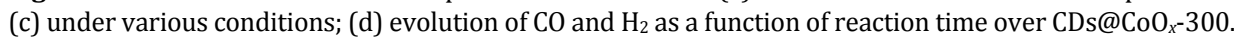

5), which is almost the same as amount of $\mathrm{CO}$ without the catalyst $(0.45 \mu \mathrm{mol} / \mathrm{h}$, column 4$)$.

To confirm the carbon origin of produced $\mathrm{CO}$, a reference reaction replacing $\mathrm{CO}_{2}$ with $\mathrm{Ar}$ under otherwise identical conditions was run (column 6). Only tiny amount of $\mathrm{H}_{2}(0.24$ $\mu \mathrm{mol} / \mathrm{h}$ ) was observed and no any $\mathrm{CO}$ was detected, implying that the $\mathrm{CO}$ evolved is derived from the $\mathrm{CO}_{2}$ reduction rather than carbonaceous residuals of the photocatalyst itself. Under

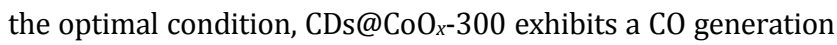
rate of $8.1 \mu \mathrm{mol} / \mathrm{h}$ with a high selectivity of $89.3 \%$ (column 9), which is obviously higher than those other analogical reported

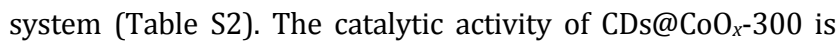
superior to that of commercial $\mathrm{Co}_{3} \mathrm{O}_{4}$ (column 7, $5.9 \mu \mathrm{mol} / \mathrm{h}$, $67.8 \%$ ) and bare $\mathrm{Co}_{3} \mathrm{O}_{4}$ (column $8,7 \mu \mathrm{mol} / \mathrm{h}, 73.7 \%$ ). In addi-

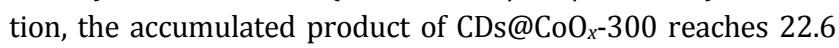
$\mu \mathrm{mol}$ of $\mathrm{CO}$ after $4 \mathrm{~h}$ reaction (Fig. $6(\mathrm{~d})$ ). The gradual decrease in the $\mathrm{CO}_{2}$-to-CO conversion rate with a long time reaction is mainly attributed to the exhaustion of the photosensitizer $[62,63]$.

\subsection{Study on the photocatalytic mechanism and process}

To further elucidate the synergistic effect between the CDs and $\mathrm{CoO}_{x}$, the electrochemical, optical and photoelectrochemical experiments were conducted as following.

In general, the WOCs can be oxidized by photogenerated oxides to high-valence state active species during water oxidation process. This means that the half wave potential $E_{1 / 2}\left(E_{1 / 2}\right.$
$\left.=\left(E_{\mathrm{pa}}+E_{\mathrm{pc}}\right) / 2\right)$ of the photosensitizer $\left(\left[\mathrm{Ru}(\mathrm{bpy})_{3}\right] \mathrm{Cl}_{2}\right)$ must be higher than the onset potential of the catalyst. The CV meas-

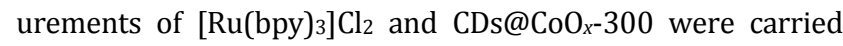
out in $80 \mathrm{mM}$ borate buffer (pH 9.0) (Fig. S12). The $E_{1 / 2}$ of $\left[\mathrm{Ru}(\mathrm{bpy})_{3}\right]^{2+/ 3+}(1.31 \mathrm{~V}$ vs $\mathrm{Ag} / \mathrm{AgCl})$ is obviously larger than onset potential of $\mathrm{CDs} @ \mathrm{CoO}_{x}-300$ (1.19 V vs Ag/AgCl), indicat-

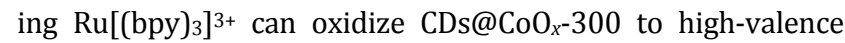
state active species and then catalyze oxidation of $\mathrm{H}_{2} \mathrm{O}$ [8]. In

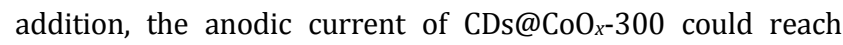
approximately $220 \mu \mathrm{A}$ at $1.50 \mathrm{~V}$, which represents a strong catalytic current for water oxidation.

Then the transient photocurrent response of CDs, bare $\mathrm{CoO}_{x}$ and $\mathrm{CDs} @ \mathrm{CoO}_{x}-300$ were recorded by chopping the light on and off at a constant potential of $1.00 \mathrm{~V}_{\text {RHE. }}$ As shown in Fig. 7(a), there is almost no photocurrent for the blank run and single CDs. Sample CDs@CoO $x-300$ possesses a distinct enhancement in photocurrent value when compared with $\mathrm{Co}_{3} \mathrm{O}_{4}$ and CDs, suggesting an enhanced separation and transfer of photogenerated charge carriers of $\left[\mathrm{Ru}(\mathrm{bpy})_{3}\right] \mathrm{Cl}_{2}$ with the assist of CDs@CoO $x-300$.

To validate the above analysis, photoluminescence (PL) spectra as a powerful instrument were conducted to analyze the carrier separation (electron-hole pairs) efficiency of the as-prepared samples under the excitation wavelength of $398 \mathrm{~nm}$. As shown in Fig. 7(b), the bare $\left[\mathrm{Ru}(\mathrm{bpy})_{3}\right] \mathrm{Cl}_{2}$ aqueous solution exhibits a strong emission at about $600 \mathrm{~nm}$ owing to a recombination of photoexcited charge carriers. The addition of CDs@ $\mathrm{CoO}_{x}-300$ into the $\left[\mathrm{Ru}(\mathrm{bpy})_{3}\right] \mathrm{Cl}_{2}$ solution results in a 
(a)

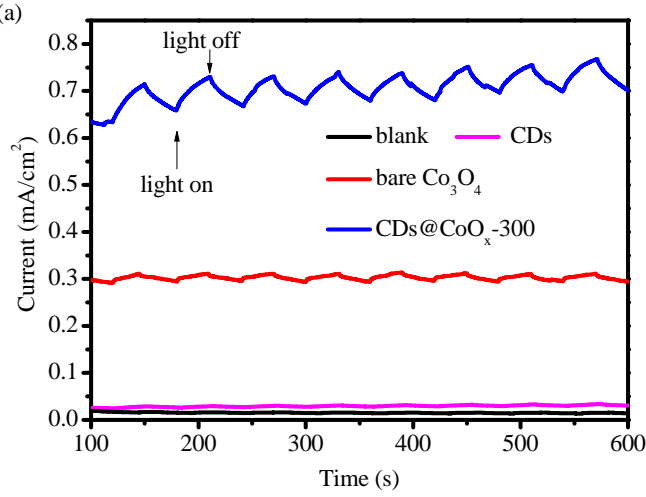

(c)

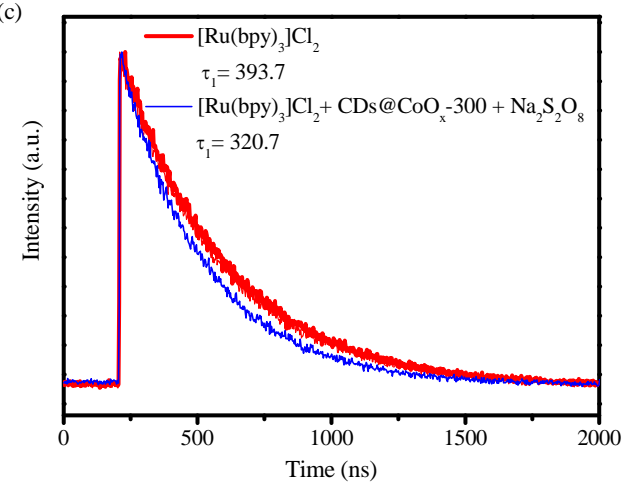

(b)

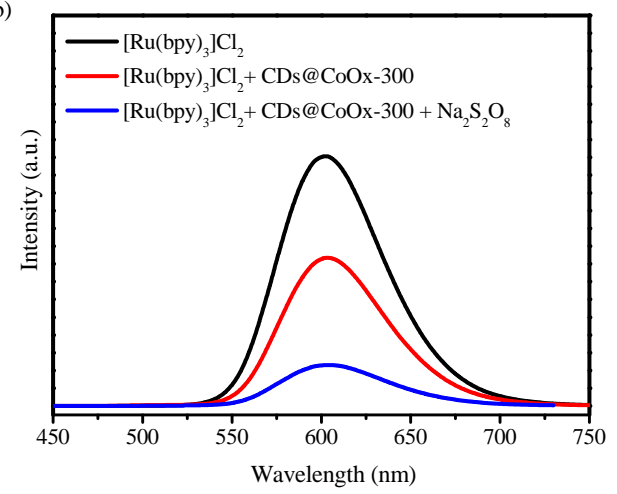

(d)

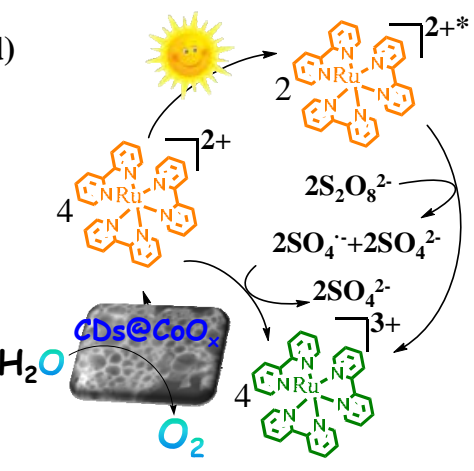

Fig. 7. Transient photocurrent responses curves in $1 \mathrm{mM}\left[\mathrm{Ru}(\mathrm{bpy})_{3}\right] \mathrm{Cl}_{2}$ solution (a), steady-state PL spectra (b), time-resolved PL spectra (c) and

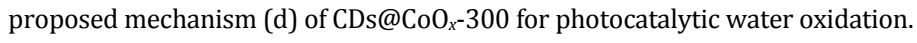

more obvious PL quenching than that of blank $\left[\mathrm{Ru}(\mathrm{bpy})_{3}\right] \mathrm{Cl}_{2}$, suggesting reduced recombination of charge carriers in $\left[\mathrm{Ru}(\mathrm{bpy})_{3}\right] \mathrm{Cl}_{2} / \mathrm{CDs} @ \mathrm{CoO}_{x}-300$ system. When $\mathrm{Na}_{2} \mathrm{~S}_{2} \mathrm{O}_{8}$ was further added, the photoluminescence intensity exhibits a dramatic decline, which signifies that the electrons are consumed by the $\mathrm{Na}_{2} \mathrm{~S}_{2} \mathrm{O}_{8}$ when the $\left[\mathrm{Ru}(\mathrm{bpy})_{3}\right] \mathrm{Cl}_{2}$ is excited.

Furthermore, time-resolved PL measurements were also studied. The lifetime of photosensitizer can be defined as the decay time from initial intensity to $1 /$ e of the initial intensity. As shown in Figs. 7(c) and S11, the corresponding fluorescence lifetimes of $\left[\mathrm{Ru}(\mathrm{bpy})_{3}\right] \mathrm{Cl}_{2} / \mathrm{Na}_{2} \mathrm{~S}_{2} \mathrm{O}_{8} / \mathrm{CDs} @ \mathrm{CoO}_{x}-300$ and $\left[\mathrm{Ru}(\mathrm{bpy})_{3}\right]^{2+}$ are 320.7 and $393.7 \mathrm{~ns}$, respectively. Consequently, the shorter decay lifetime has the faster interfacial charge transfer, which corroborates the results of steady-state PL and analysis transient photocurrent response.

The overpotentials of the bare $\mathrm{Co}_{3} \mathrm{O}_{4}(1.35 \mathrm{~V}$ vs $\mathrm{Ag} / \mathrm{AgCl})$ and CDs@CoO $x^{-} 300$ (1.08 V vs $\left.\mathrm{Ag} / \mathrm{AgCl}\right)$ at $1 \mathrm{~mA} / \mathrm{cm}^{2}$ in linear sweep voltammeter (LSVs) are shown in Fig. S13(a). Although CDs has no water oxidation activity, the electrocatalytic activity of $\mathrm{CoO}_{x}$ is greatly improved after the CDs incorporating. Meanwhile, to further acquire a deeper understanding of the change charge transfer kinetics with/without CDs and the separation efficiency of photogenerated charge carriers during water oxidation, the electrochemical impedance spectroscopy (EIS) measurements were conducted in $80 \mathrm{mM}$ borate buffer (pH 9.0). As shown in Fig. S9(b), compared with bare $\mathrm{Co}_{3} \mathrm{O}_{4}$, the CDs@CoO $x$-300 shows much smaller arc radius, revealing that the introduction of CDs makes interfacial charge transfer faster, and separation efficiency of photogenerated charge carriers higher. The EIS results were fitted with a model circuit (inset in Fig. S13(b)). The high frequency semicircle corresponds to the contact resistance (Re), and the semicircle in medium-frequency region represents the charge transfer resistance of the electrode/electrolyte interface $(R 1)$. The low frequency straight line is corresponds to Warburg impedance (W2) [64].

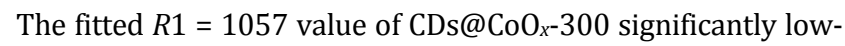
er than those of bare $\mathrm{Co}_{3} \mathrm{O}_{4}(R 1=2415)$, indicating the superior

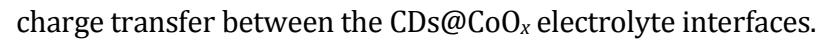

Based on the above discussions, a plausible mechanism for the CDs@CoO -300 in the typical photocatalytic water oxidation process is proposed. As shown in Fig. 7(d), the orange $\left[\mathrm{Ru}(\mathrm{bpy})_{3}\right]^{2+}$ is firstly excited to $\left[\mathrm{Ru}(\mathrm{bpy})_{3}\right]^{2+*}$ under the visible light irradiation. Subsequently, $\mathrm{Na}_{2} \mathrm{~S}_{2} \mathrm{O}_{8}$ reacts with the $\left[\mathrm{Ru}(\mathrm{bpy})_{3}\right]^{2+^{*}}$ to generate oxidant of $\left[\mathrm{Ru}(\mathrm{bpy})_{3}\right]^{3+}, \mathrm{SO}_{4}{ }^{2-}$ and $\mathrm{SO}_{4}{ }^{--}$. Then the $\mathrm{SO}_{4}{ }^{--}$with a potential of $2.4 \mathrm{~V}$ vs. NHE reacts with the two additional $\left[\mathrm{Ru}(\mathrm{bpy})_{3}\right]^{2+}$ in solution to form two $\left[\mathrm{Ru}(\mathrm{bpy})_{3}\right]^{3+}$. The produced $\left[\mathrm{Ru}(\mathrm{bpy})_{3}\right]^{3+}$ oxidizes CDs@CoO -300 to high valence state, which is responsible for the formation of $\mathrm{O}-\mathrm{O}$ bonding. The restored $\left[\mathrm{Ru}(\mathrm{bpy})_{3}\right]^{2+}$ starts next cycle again.

As shown in Fig. 8(a), the addition of CDs@ $\mathrm{CoO}_{x}-300$ into the $\left[\mathrm{Ru}(\mathrm{bpy})_{3}\right]^{2+}$ solution in the presence of TEOA can obviously reduce the $\mathrm{PL}$ intensity than that of only $\left[\mathrm{Ru}(\mathrm{bpy})_{3}\right]^{2+}$ or with the catalyst. Meanwhile, transient absorption spectra (Fig. 8(b)) demonstrate that $\mathrm{CDs} @ \mathrm{CoO}_{x}-300$ can accelerate the luminescence decay of $\left[\mathrm{Ru}(\mathrm{bpy})_{3}\right] \mathrm{Cl}_{2}$ from 387.9 to $271.0 \mathrm{~ns}$. In 
(a)

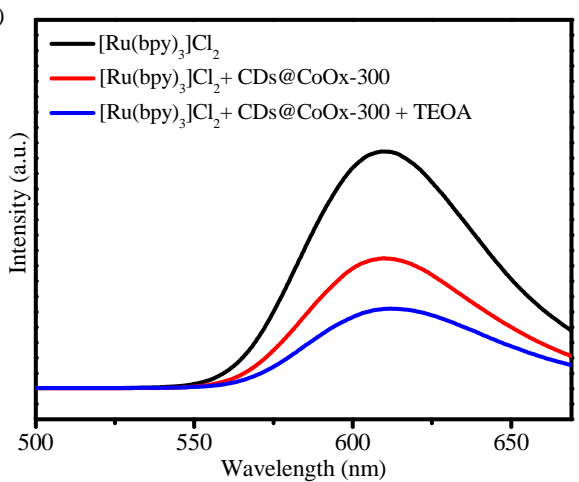

(c)

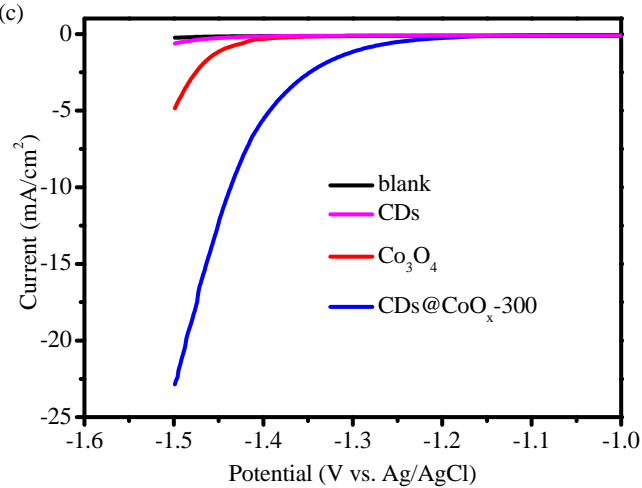

(b)

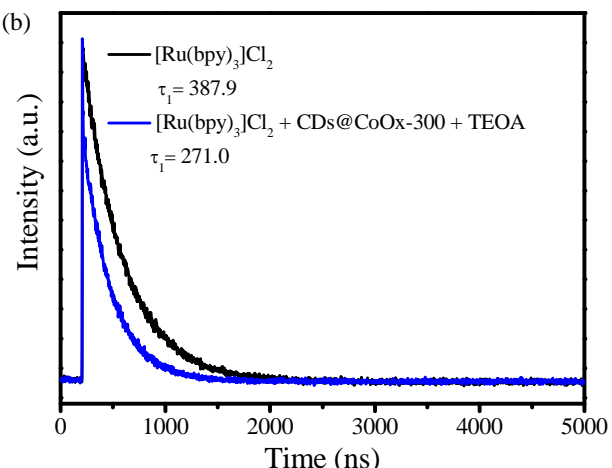

(d)

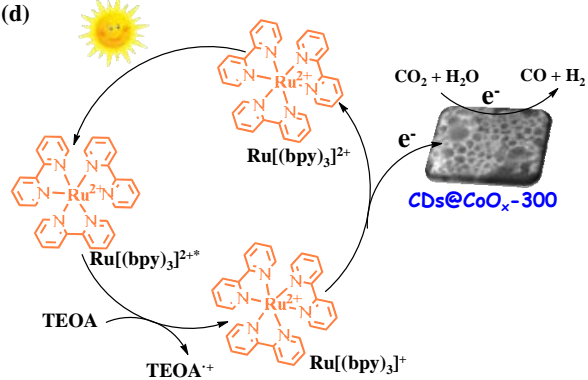

Fig. 8. Steady-state PL spectra (a), time-resolved PL spectra (b); LSV curves (c) and proposed mechanism (d) of CDs@CoO $\mathrm{CD}_{x}-300$ for photocatalytic CO 2 reduction.

addition, the $\mathrm{CO}_{2}$ reduction activities of bare $\mathrm{Co}_{3} \mathrm{O}_{4}$ and CDs@ $\mathrm{CoO}_{x}-300$ were evaluated by LSV in $0.5 \mathrm{M} \mathrm{Na}_{2} \mathrm{SO}_{4}$ solution (Fig. 8(c)). Although CDs shows no $\mathrm{CO}_{2}$ reduction activity, the

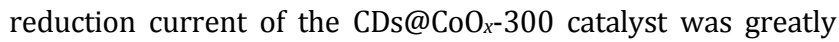
enhanced compared with that of bare $\mathrm{Co}_{3} \mathrm{O}_{4}$. The corresponding findings of PL spectra and LSV measurement indicate that the CDs@CoO $x_{x}-300$ could efficiently expedite the separation and transfer of light-induced charges, and thus improving the $\mathrm{CO}_{2}$ photoreduction activity.

According to the previously reported works $[34,65]$, the possible process of the $\mathrm{CO}_{2}$ photoreduction mechanism cata-

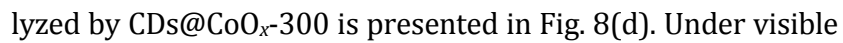
light irradiation, the photosensitizer $\left[\mathrm{Ru}(\mathrm{bpy})_{3}\right]^{2+}$ is motivated to the excited state $\left[\mathrm{Ru}(\mathrm{bpy})_{3}\right]^{2+*}$, which is reductively quenched by TEOA to form a reduced state $\left[\mathrm{Ru}(\mathrm{bpy})_{3}\right]^{+}$. Afterward, the excited electrons of $\left[\mathrm{Ru}(\mathrm{bpy})_{3}\right]^{+}$delocalizes and migrate to the $\mathrm{CDs@CoO}$-300 catalyst to reduce the $\mathrm{CO}_{2}$ molecules to the CO product, while the photosensitizer recover to the initial state. Alternatively, the electrons can react with the protons to form $\mathrm{H}_{2}$.

Based on the above analysis and photocatalytic experiments, these results demonstrated that the incorporation of CDs into $\mathrm{CoO}_{x}$ plays a critical role in promoting the photocatalytic water oxidation and $\mathrm{CO}_{2}$ reduction activities. Specifically, the CDs can serve as a nanosized template to regulate the crystallization process and then change the morphology according to the TEM results (Figs. 3(b) and S3). Thus, when coupled with

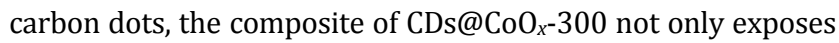

more active sites but also facilitates electron transport. Ultimately, the synergistic effect between $\mathrm{CoO}_{x}$ and $\mathrm{CDs}$ boosted excellent photocatalytic behavior for water oxidation and $\mathrm{CO}_{2}$ reduction.

\subsection{Stability study}

Besides the photocatalytic activity, the stability is another crucial factor parameter of a catalyst for further practical applications. Therefore, the cycling experiments of CDs@CoO $x-300$ were conducted to visually evaluate the property of the catalyst. As shown in Fig. 9(a) and 9(b), after the five recycling runs, there is no significant change in the total amount of $\mathrm{O}_{2}$ and $\mathrm{CO}$ evolution. In addition, the $\mathrm{CDs@CoO}_{x}-300$ catalyst before and after photocatalytic reaction were examined by XPS. Fig. 9(c) and 9(d) show the similarity of Co $2 p$ peak shapes and the satellite peaks of $\mathrm{CDs} @ \mathrm{CoO}_{x}-300$ catalyst before and after reaction for water oxidation and $\mathrm{CO}_{2}$ reduction, respectively, suggesting that there is no change in the valence state of Co $2 p$. In all, the cycling experiments and XPS

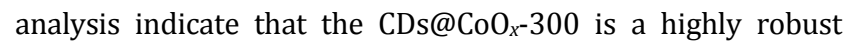
catalyst during the photocatalytic reaction process.

\section{Conclusions}

In this work, we successfully synthesized a spongy porous CDs@ $\mathrm{CoO}_{x}$ bifunctional photocatalyst by a facile hydrothermal and calcination method for enhancing the $\mathrm{CoO}_{x}$ water oxidation 

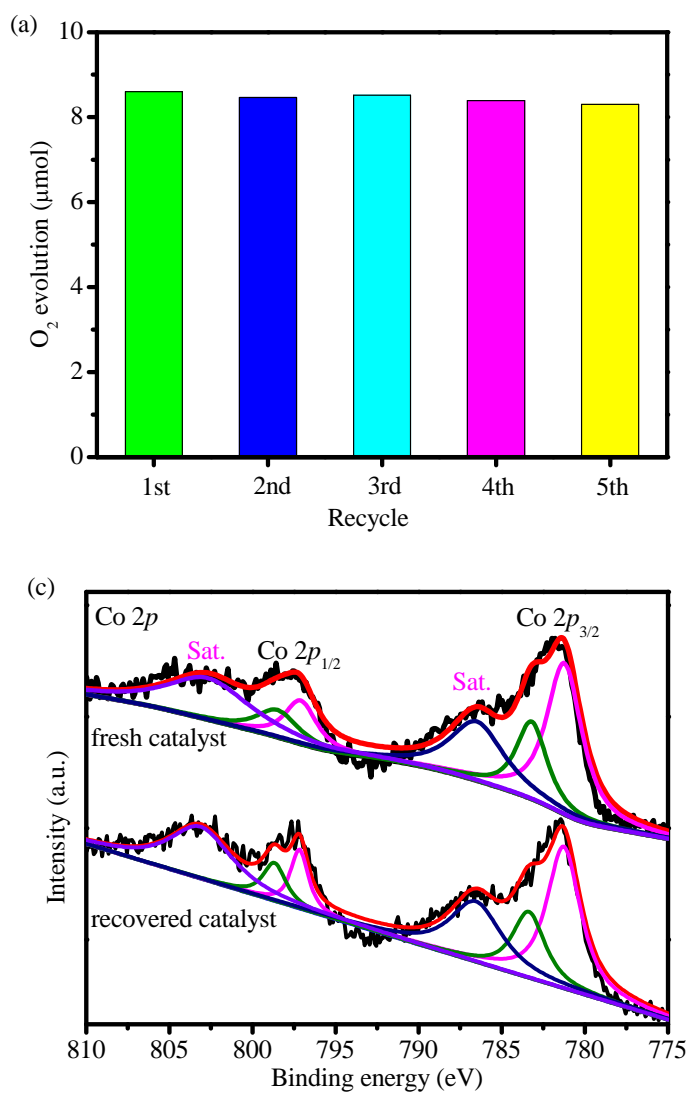

(b)

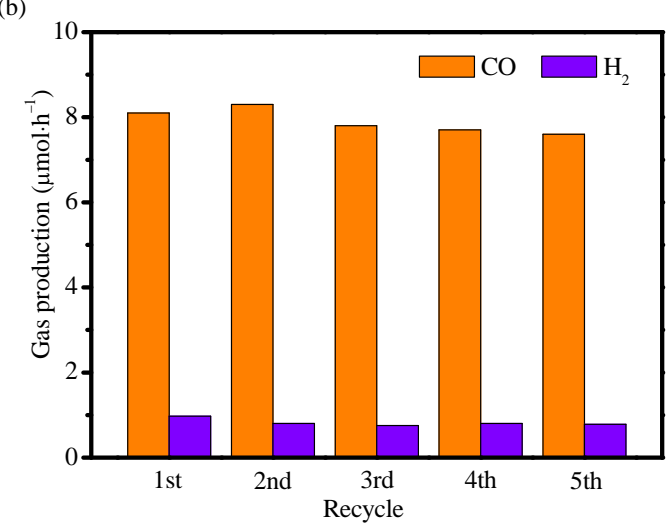

(d)

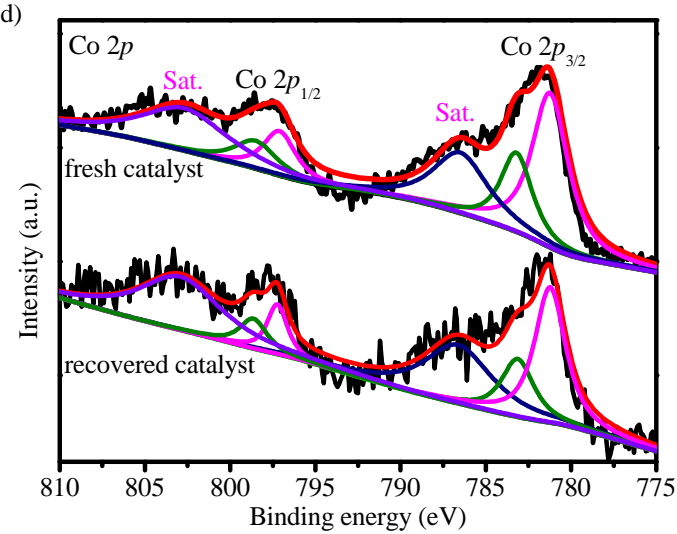

Fig. 9. Amount of $\mathrm{O}_{2}$ (a) and $\mathrm{CO} / \mathrm{H}_{2}$ (b) evolution in recycling tests and XPS spectra of fresh and used CDs@CoO -300 sample for water oxidation (c) and $\mathrm{CO}_{2}$ reduction $(\mathrm{d})$.

and $\mathrm{CO}_{2}$ reduction activities for the first time. The morphological difference induced by the calcination temperature affects

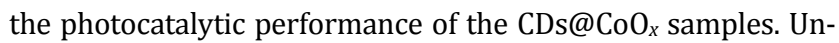
der the optimal conditions, it is notable that a maximum $\mathrm{O}_{2}$ yield of $40.4 \%$ and an outstanding AQE of $58.6 \%$ are obtained over CDs@ $\mathrm{CoO}_{x}-300$. Furthermore, the optimized sample CDs@CoO -300 shows a CO selectivity of $89.3 \%$ and a CO generation rate of $8.1 \mu \mathrm{mol} / \mathrm{h}$. Based on the photocatalytic control experiments, optical and electrochemical measurement, spongy

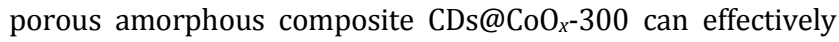
enhance photocatalytic performances. The cycling experiments

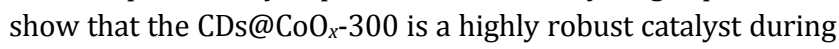
the photocatalytic reaction process. This work provides new insight for the design of feasible and stable cobalt-based carbon hybrids with high photocatalytic performance.

\section{References}

[1] Q. Wang, T. Hisatomi, Q. Jia, H. Tokudome, M. Zhong, C. Wang, Z. Pan, T. Takata, M. Nakabayashi, N. Shibata, Y. Li, I. D. Sharp, A. Kudo, T. Yamada, K. Domen, Nat. Mater., 2016, 15, 611-615.

[2] X. Li, J. Wen, J. Low, Y. Fang, J. Yu, Sci. China Mater., 2014, 57, 70-100.

[3] Y. Wang, Z. Zhang, L. Zhang, Z. Luo, J. Shen, H. Lin, J. Long, J. C. S. Wu, X. Fu, X. Wang, C. Li, J. Am. Chem. Soc., 2018, 140, 14595-14598.
[4] Z. Wang, C. Li, K. Domen, Chem. Soc. Rev., 2019, 48, 2109-2125.

[5] J. Ran, M. Jaroniec, S. Z. Qiao, Adv. Mater., 2018, 30, 1704649.

[6] Y. Xiao, Y. Qi, X. Wang, X. Wang, F. Zhang, C. Li, Adv. Mater., 2018, 30, 1803401.

[7] X. Li, J. Yu, M. Jaroniec, X. Chen, Chem. Rev., 2019, 119, 3962-4179.

[8] R. Li, Chin. J. Catal., 2018, 39, 1180-1188.

[9] M. Shi, G. N. Li, J. M. Li, X. Jin, X. P. Tao, B. Zeng, E. A. Pidko, R. G. Li, C. Li, Angew. Chem. Int. Ed., 2020, 59, 6590-6595.

[10] R. Shen, J. Xie, Q. Xiang, X. Chen, J. Jiang, X. Li, Chin. J. Catal., 2019, 40, 240-288.

[11] Y. Ren, D. Zeng, W. J. Ong, Chin. J. Catal., 2019, 40, 289-319.

[12] R. Li, Chin. J. Catal., 2017, 38, 5-12.

[13] Z. Li, L. Zhang, Y. Liu, C. Shao, Y. Gao, F. Fan, J. Wang, J. Li, J. Yan, R. Li, C. Li, Angew. Chem. Int. Ed., 2020, 59, 935-942.

[14] Z. Chen, Q. E. Huang, B. K. Huang, F. X. Zhang, C. Li, Chin. J. Catal., 2019, 40, 38-42.

[15] M. Zheng, Y. Ding, L. Yu, X. Du, Y. Zhao, Adv. Funct. Mater., 2017, $27,1605846$.

[16] J. W. Wang, W. J. Liu, D. C. Zhong, T. B. Lu, Coordin. Chem. Rev., 2019, 378, 237-261.

[17] X. Lin, S. Wang, W. Tu, H. Wang, Y. Hou, W. Dai, R. Xu, ACS Appl. Energy Mater., 2019, 2, 7670-7678.

[18] Y. Ma, Z. Wang, X. Xu, J. Wang, Chin. J. Catal., 2017, 38, 1956-1969.

[19] X. Li, C. Liu, D. Wu, J. Li, P. Huo, H. Wang, Chin. J. Catal., 2019, 40, 928-939.

[20] S. Wang, Y. Hou, X. Wang, ACS Appl. Mater. Interfaces, 2015, 7, 


\section{Graphical Abstract}

Chin. J. Catal., 2020, 41: 1826-1836 doi: 10.1016/S1872-2067(20)63646-4

Amorphous $\mathrm{CoO}_{x}$ coupled carbon dots as a spongy porous bifunctional catalyst for efficient photocatalytic water oxidation and $\mathrm{CO}_{2}$ reduction

Wanjun Sun, Xiangyu Meng, Chunjiang Xu, Junyi Yang, Xiangming Liang, Yinjuan Dong, Congzhao Dong, Yong Ding *

Lanzhou University;

Lanzhou Institute of Chemical Physics, Chinese Academy of Sciences

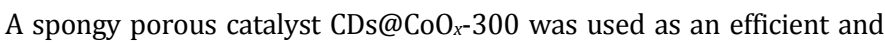
stable bifunctional photocatalyst for water oxidation and $\mathrm{CO}_{2}$-to- $\mathrm{CO}$ conversion, in which the boosted photocatalytic behavior is attributed to the synergistic effect between $\mathrm{CoO}_{x}$ and CDs.

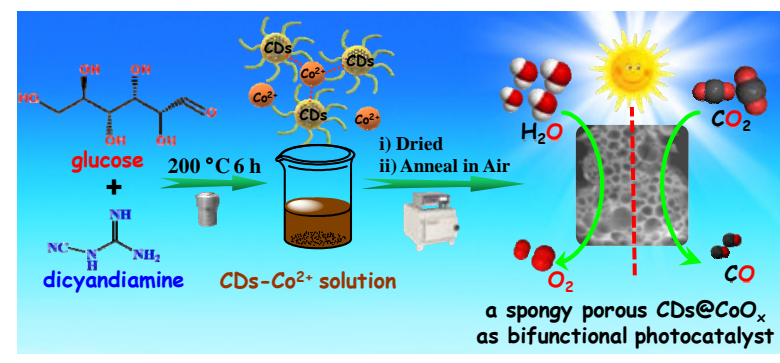

[41] P. Wang, G. Yin, Q. Bi, X. Huang, X. Du, W. Zhao, F. Huang, ChemCatChem, 2018, 10, 3854-3861.

[42] X. Xu, R. Ray, Y. Gu, H. J. Ploehn, L. Gearheart, K. Raker, W. A. Scrivens, J. Am. Chem. Soc., 2004, 126, 12736-12737.

[43] H. Li, X. He, Z. Kang, H. Huang, Y. Liu, J. Liu, S. Lian, C. A. H. Tsang, X. Yang, S. T. Lee, Angew. Chem. Int. Ed., 2010, 49, 4430-4434.

[44] H. Yu, R. Shi, Y. Zhao, G. I. Waterhouse, L. Z. Wu, C. H. Tung, T. Zhang, Adv. Mater., 2016, 28, 9454-9477.

[45] R. Wang, K. Q. Lu, Z. R. Tang, Y. J. Xu, J. Mater. Chem. A, 2017, 5, 3717-3734.

[46] X. Y. Kong, W. L. Tan, B. J. Ng, S. P. Chai, A. R. Mohamed, Nano Res., 2017, 10, 1720-1731.

[47] H. Li, X. Zhang, D. R. MacFarlane, Adv. Energy Mater., 2015, 5, 1401077.

[48] X. Meng, C. Zhang, C. Dong, W. Sun, D. Ji, Y. Ding, Chem. Eng. J., 2020, 389, 124432.

[49] T. Feng, Q. Zeng, S. Lu, M. Yang, S. Tao, Y. Chen, Y. Zhao, B. Yang, ACS Sustain. Chem. Eng., 2019, 7, 7047-7057.

[50] L. Zhu, G. Xu, Q. Song, T. Tang, X. Wang, F. Wei, Q. Hu, Sensor Actuat. $B, \mathbf{2 0 1 6}, 231,506-512$.

[51] X. Wu, J. Zhao, L. Wang, M. Han, M. Zhang, H. Wang, H. Huang, Y. Liu, Z. Kang, Appl. Catal. B, 2017, 206, 501-509.

[52] L. Wang, X. Wu, S. Guo, M. Han, Y. Zhou, Y. Sun, H. Huang, Y. Liu, Z. Kang, J. Mater. Chem. A, 2017, 5, 2717-2723.

[53] C. Y. Liang, W. Xia, C. Z. Yang, Y. C. Liu, A. M. Bai, Y. J. Hu, Carbon, 2018, 130, 257-266.

[54] X. Li, J. Wei, Q. Li, S. Zheng, Y. Xu, P. Du, C. Chen, J. Zhao, H. Xue, Q. Xu, H. Pang, Adv. Funct. Mater., 2018, 28, 1800886.

[55] Y. Feng, J. Wei, Y. Ding, J. Catal., 2016, 339, 186-194.

[56] C. Han, L. Ge, C. Chen, Y. Li, X. Xiao, Y. Zhang, L. Guo, Appl. Catal. B, 2014, 147, 546-553.

[57] K. Qian, W. Huang, Z. Jiang, H. Sun, J. Catal., 2007, 248, 137-141.

[58] Q. Han, D. Sun, J. Zhao, X. Liang, Y. Ding, Chin. J. Catal., 2019, 40, 953-958.

[59] X. Meng, Y. Dong, Q. Hu, Y. Ding, ACS Sustain. Chem. Eng., 2018, 7, 1753-1759.

[60] J. W. Nai, S. Wang, X. W. D. Lou, Sci. Adv., 2019, 5, eaax5095.

[61] Y. Wang, S. Wang, X. W. D. Lou, Angew. Chem. Int. Ed., 2019, 58, 17236-17240.

[40] Z. Lin, C. Du, B. Yan, G. Yang, J. Catal., 2019, 372, 299-310. 
[62] S. Wang, B. Y. Guan, X. W. Lou, Energy Environ. Sci., 2018, 11, 306-310.

[63] T. Ouyang, H. H. Huang, J. W. Wang, D. C. Zhong, T. B. Lu, Angew. Chem. Int. Ed., 2017, 56, 738-743.
[64] M. Xiao, Y. Meng, Y. Li, X. Liu, X. Ke, G. Ren, F. Zhu, Appl. Surf. Sci., 2019, 494, 532-539.

[65] W. Chen, B. Han, C. Tian, X. Liu, S. Liang, H. Deng, Z. Lin, Appl. Catal. $B, 2019,244,996-1003$.

\title{
无定形 $\mathrm{CoO}_{x}$ 耦合碳点构筑海绵状多孔结构的双功能光催化剂用于提高 水氧化和二氧化碳还原性能
}

\author{
孙万军 ${ }^{\mathrm{a}, \dagger}$, 孟翔宇 ${ }^{\mathrm{a}, \dagger}$, 徐春江 ${ }^{\mathrm{a}}$, 杨峻懿 ${ }^{\mathrm{a}}$, 梁向明 ${ }^{\mathrm{a}}$, 董银娟 ${ }^{\mathrm{a}}$, 董聪朝 ${ }^{\mathrm{a}}$, 丁 勇, ${ }^{\mathrm{a}, \mathrm{*},}$ \\ 兰州大学化学化工学院, 甘肃省有色金属化学与资源利用重点实验室, 功能有机分子化学国家重点实验室, 甘肃兰州730000 \\ ${ }^{\mathrm{b}}$ 中国科学院兰州化学物理研究所, 羰基合成与选择氧化国家重点实验室, 甘肃兰州730000
}

摘要: 随着化石燃料大量使用带来的温室效应、能源贵乏以及环境污染问题日趋严重, 寻找清洁高效的可再生能源用做传 统化石燃料的替代品, 已经成为当今的研究重点. 太阳能驱动的水分解制备氢气和 $\mathrm{CO}_{2}$ 还原为 $\mathrm{CO}$, 不仅可以降低大气中 $\mathrm{CO}_{2}$ 的浓度, 而且提供了理想的能源气体 $\mathrm{H}_{2}$ 和有经济价值的化学物质, 实现了太阳能的转换/储存. 整个水分解反应包含两 个半反应, 即质子还原和水的氧化. 其中水的氧化反应是一个涉及四个电子和四个质子转移的复杂过程, 需要很高的活化 能, 被认为是全分解水反应的瓶颈步骤. 此外, $\mathrm{CO}_{2}$ 还原也是光合作用的重要半反应, 是将太阳能转化为化学燃料/原料的 重要途径. 因此, 寻找一种同时具有高催化活性和稳定性的水氧化和 $\mathrm{CO}_{2}$ 还原双功能光催化剂至关重要.

本文以双氧胺和葡萄糖为原料, 通过简单的水热法脱水聚合得到碳点 $(\mathrm{CDs})$, 再与 $\mathrm{Co}\left(\mathrm{NO}_{3}\right)_{2} \cdot 6 \mathrm{H}_{2} \mathrm{O}$ 形成均匀溶液烘干后, 通过改变不同㷽烧温度 $\left(200,300,400\right.$ 和 $\left.600^{\circ} \mathrm{C}\right)$, 构筑了一系列 $\mathrm{CoO}_{x}$ 耦合碳点的海绵状多孔结构的双功能光催化剂

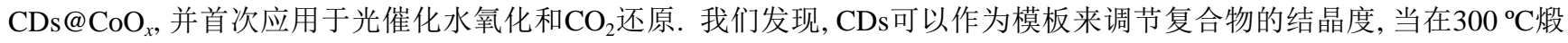
烧时得到的是无定形催化剂 $\mathrm{CDs} @ \mathrm{CoO}_{x}-300$, 相比未掺杂的 $\mathrm{Co}_{3} \mathrm{O}_{4}, \mathrm{CDs}$ 的引入在促进光催化水氧化和 $\mathrm{CO}_{2}$ 还原活性方面起

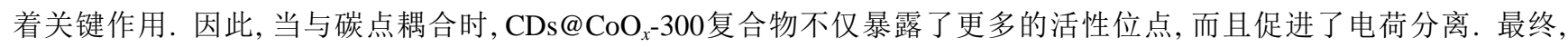
$\mathrm{CoO}_{x}$ 和CDs之间的协同作用促进了水氧化和 $\mathrm{CO}_{2}$ 还原.

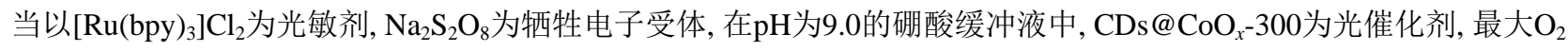
收率为 $40.4 \%$, 在 $460 \mathrm{~nm}$ 处具有 $58.6 \%$ 的表观量子效率. 同时将该催化剂 $\mathrm{CDs} @ \mathrm{CoO}_{x}-300$ 用于以 $\left[\mathrm{Ru}(\mathrm{bpy})_{3}\right] \mathrm{Cl}_{2}-\mathrm{TEOA}$ 的体系 中进行光催化还原 $\mathrm{CO}_{2}$ 时, $\mathrm{CO}$ 的生成速率为 $8.1 \mu \mathrm{mol} \mathrm{h}^{-1}$, 且 $\mathrm{CO}$ 选择性高达 $89.3 \%$, 展现出了优异的催化性能. 此外, 在水氧 化和 $\mathrm{CO}_{2}$ 还原循环测试中, 发现 5 次反应后, 催化活性无明显降低, 说明该双功能催化剂具有较高的稳定性. 本文为未来合 理构建高效、稳定的碳掺杂的钴基双功能光催化剂提供了重要的启发和研究思路.

关键词: 碳点掺杂 $\mathrm{CoO}_{x} ;$ 双功能光催化剂; 水氧化; $\mathrm{CO}_{2}$ 还原; 协同效应

收稿日期: 2020-02-25. 接受日期: 2020-03-23. 出版日期: 2020-12-05.

*通讯联系人. 电子信箱: dingyong1@lzu.edu.cn

†共同第一作者.

基金来源：国家自然科学基金(21773096); 兰州大学中央高校基本科研业务费(lzujbky-2018-k08); 甘肃省自然科学基金 (17JR5RA186).

本文的电子版全文由Elsevier出版社在ScienceDirect上出版(http://www.sciencedirect.com/science/journal/18722067). 